DOI: 10.32370/IA_2021_09_14

\title{
Organization of Experimental Work on the Formation of Musical and Aesthetic Competence of Adolescents in Out-Of-School Art Education
}

\author{
Liao Bin \\ Postgraduate student \\ Dragomanov National Pedagogical University (Kyiv, Ukraine)
}

\begin{abstract}
The article emphasizes that the state of modern art education in Ukraine and China requires the introduction into the practice of music education of students of out-of-school educational institutions of new methods aimed at forming their musical and aesthetic competence. Presented step-by-step method covers piano preparation of teenage students in two planes-performing and art-theoretical and provides for the presence of three stages: organizational-orientational, intellectual-deepening and creative-enriching. The main purpose of the first organizational and orientation stage of education was to acquire in adolescents a positive motivation for musical and aesthetic activities and the expansion of the thesaurus of musical knowledge.

The second (intellectually-deepening) stage was aimed at theoretical and practical development of musical knowledge in order to form in adolescents musical and aesthetic competence, filling musical and intonation vocabulary, expanding musical and aesthetic worldview, activating emotional impressions, comparing their own experiences with artistic content of piece of music, accumulation of musical thesaurus and musical performance experience. The third (creative-enriching) stage was aimed at developing the ability to genre-style embodiment of interpretive ideas, creative evaluation of musical phenomena on the basis of the system of values adopted in the art of music.
\end{abstract}

Key words: musical-aesthetic-competence, out-of-school art institutions, piano training, teenagers, piano teaching methods.

Актуальність. На сучасному етапі реалізації освітньої стратегії особливої ваги набуває питання формування музично-естетичної компетентності підлітків у закладах позашкільної мистецької освіти. Така тенденція простежується не тільки в Україні, а і в Китаї. Державну політику у сфері позашкільної освіти у цих країнах визначають Державна національна програма «Освіта» (Україна XXI століття), «Закон України «Про освіту» (2017p., у новій редакції з 16.01.2020p.), «Про позашкільну освіту», Концепція «Нової української школи» (2016р.), «Стратегія розвитку освіти в Китаї у XXI столітті», «Реформи розвитку базової освіти КНР». У цих документах позашкільна освіта розглядається як цілісна міжгалузева і багаторівнева система для забезпечення розвитку здібностей та таланту обдарованих дітей та молоді.

Зокрема відомий педагог О. Бруднов зазначає наступне: «Відмінність мережі установ позашкільної освіти дітей від інших освітніх установ полягає в тому, що в них дитина проходить зовсім інший освітній шлях... Ми не тільки даємо їй інформацію, а 
включаємо у процес, що сприяє освоєнню різних галузей людської діяльності, знання, дозволяє набувати вміння та навички, вдивлятися в майстерність своїх рук, в досконалість свого педагога, і на основі цього робити власний вибір і визначати шляхи розвитку» [1, с. 26-32].

Теоретико-методологічна складова музично-естетичного розвитку учнів підліткового віку представлена у дослідженнях Н. Миропольської, Г. Падалки, Л. Паньків, О. Ростовського, О. Рудницької, Л. Хлєбнікової, Г. Шевченко, О. Щолокової. Частково означена проблема знайшла відображення у наукових розвідках українських (Г. Бриль, В. Мішедченко, О. Сбітнєвої, І. Слятіної) та китайських (Лі Джуйцін, Тженг Чен-Лі, Тун Даоцзинь, Чжоу Гуанрен) науковців.

Водночас, огляд наукової літератури засвідчив, що проблема формування музично-естетичної компетентності підлітків у закладах позашкільної спеціалізованої мистецької освіти ще не стала предметом цілісного дослідження.

Mema cmammi - презентувати поетапну методику формування музичноестетичної компетентності підлітків у закладах позашкільної мистецької освіти.

Виклад основного матеріалу. Авторська експериментальна методика передбачала цілеспрямоване та поетапне формування визначених на попередньому етапі дослідження компонентів музично-естетичної компетентності (мотиваційно-цільового, комунікативно-емоційного, ціннісно-інтелектуального). Вона реалізувалася на основі таких принципів: ідеального та еталонного в музичному мистецтві, культурної самоідентифікації, міжкультурного діалогу, творчого універсалізму, а також педагогічних умов: створення у закладах позашкільної мистецької освіти художньоестетичного середовища, розвитку у підлітків здатності до повноцінного сприйняття музичних творів, постійного оновлення музично-інтонаційного словника, вивчення в процесі навчання фортепіанної музики для дітей та юнацтва, оволодіння підлітками навичками художньої інтерпретації музичних творів та формування музичноестетичного світогляду.

Формування музично-естетичної компетентності підлітків здійснювалось за допомогою таких музично-естетичних форм навчання: усні (роз'яснення змісту музичного твору); практичні (порівняння з іншими творами); творчі (демонстрація окремих уривків 3 творів, інтерпретація музичних творів); проблемно-пошукові 
(створення проблемних ситуацій під час фортепіанних занять); самостійного сприйняття, вивчення та інтерпретування мистецьких творів.

Проведення методики формування музично-естетичної компетентності підлітків здійснювалося впродовж трьох етапів: організаційно-орієнтаційного, інтелектуальнопоглиблюючого, творчо-збагачувального, кожен з яких мав свою мету, завдання, засоби педагогічного впливу та спеціально розроблене методичне забезпечення. Етапи було сплановано таким чином, аби на кожному з них відбувалось поступове формування усіх компонентів музично-естетичної компетентності. При цьому ми враховували, що це має бути безперервним процесом музично-естетичного саморозвитку і самовдосконалення.

Так, на першому (організаційно-орієнтаційному) етапі увага зосереджувалася на формуванні позитивної мотивації підлітків до музично-естетичної діяльності та розширенні тезаурусу музичних знань. Проведення даного етапу здійснювалось на основі міждисциплінарного та гедоністичного підходів, 3 урахуванням принципів культурної самоідентифікації та міжкультурного діалогу, вікових особливостей учнів підліткового віку, а також реалізації такої педагогічної умови як створення в закладах позашкільної мистецької освіти художньо-естетичного середовища, розвитку здатності до повноцінного сприйняття музичних творів та розвиток музично-естетичного світогляду учнів. Завдання цьвого етаnу полягали в окресленні провідних напрямів фортепіанного розвитку учнів на період експерименту, формуванні зацікавленості музичним мистецтвом, установки на естетичне сприймання дійсності, активізації емоційно-чуттєвої сфери підлітків. Для вирішення поставлених завдань використовувалися такі форми роботи як пояснення змісту музичного твору і порівняння з іншими творами, а також ігрові, пізнавальні, дискусійні методи.

Загальновідомо, що сформована музично-естетична компетентність підлітків включає розвинуту здатність сприймати твори мистецтва. Це стосується, в першу чергу, їх образного змісту, а також виражає прагнення учнів усвідомити переживання, втілені композитором, художником, балетмейстером у своїх творах, отримати насолоду від досконалості їх форм. При цьому, здатність до сприйняття і розуміння мистецтва змінюється разом з естетичним зростанням учнів.

3 метою розвитку здатності до сприйняття творів різних видів мистецтв учням експериментальної групи було запропоновано проблемно-пізнавальні завдання: 
прослухати, оглянути та проаналізувати низку живописних, скульптурних та архітектурних творів.

Для його виконання були використані методи художньо-естетичного наведення та естетичного оцінювання, відібрані живописні твори різних жанрів: пейзаж (О. Кокошка «Буревій», Ма Юань «Гірською стежкою по весні», Лі Кежань «Кленовий ліс у Данься»); портрет (К. Малевич «Квіткарка», О. Кричевський «Сім’я», Чжао Менфу «Монах у червоному одязі», Ло Чжунлі «Батько»; історичний живопис (Ф. Красицький «Гість із Запоріжжя», О. Мурашко «Похорон кошового», І. Рєпін «Козаки пишуть письмо турецькому султану»; народне мистецтво (І. Падалка «Фотограф на селі», I. Марчук «Очі дивляться нам услід», М. Приймаченко «Горіховий звір».

При сприйнятті творів живопису учням необхідно було дотримуватися таких порад: дивлячись на картину, не обмежуватися лише спогляданням; зрозуміти, яку роль виконують композиція і колорит, без яких вона є тільки натуралістичним переказом дійсності; дивлячись на пейзаж, не задовольнятися лише тим, що зображено, адже метою художника було не сліпе їі копіювання, а передача почуттів.

Під час сприйняття скульптурних зразків (В. Архипенко «Жінка, що йде», В. Татлін «Конструкція у блакитному й жовтому», Р. Петрук «Мойсей», Т. Бертель «Меркурій із сопілкою», А. Канова «Амур і Психея») увага учнів приверталась на особливості та відмінності скульптури минулих віків та сучасності; на загальну структуру, фактуру, і матеріал, на новації і творчі пошуки кожного митця.

В якості архітектурних були наведені приклади будівель у стилі класицизму в різних містах України: Палац Розумовського в Батурині (Ч. Камерон і А. Рінальді), головний корпус Київського національного університету імені Т. Шевченка (В. Беретті), Палац Потоцьких в Одесі (Ф. Буффо). Це дало можливість прослідкувати особливості розвитку мистецтва архітектури епохи класицизму. Під час ознайомлення з цими спорудами учні з' ясовували, що мистецтво класицизму - це ідеал гармонії, довершеності й досконалості. Цей стиль заснований на принципах античності і керується його правилами та канонами; класицизм прагнув виразити піднесені, героїчні й моральні ідеали, створити ясні та органічні образи. Для будівель, створених у цьому художньому стилі, характерні масивні і досить стійкі конструктивні елементи прямокутних і арочних форм. 
Виконання цих завдань супроводжувалося інтерактивними іграми («Склади літературне оповідання», «Уяви, що ти митець», «Інтерв’ю» тощо), а також пізнавальнопошуковими завданнями: знайти подібності в творах одного жанру, виявити особливості архітектурного стилю або живописного жанру, відзначити основні виражальні засоби в образотворчому мистецтві, скульптурі та архітектурі, дати назву представленій картині або скульптурі.

Оцінювання вправ здійснювалось за 12-ти бальною шкалою за такими вимогами: уміння сприймати твір глибоко, цілісно, з урахування всіх складових художньої мови, комплексне сприйняття твору, враховуючи його контекст і підтекст, емоційна реакція на сприйнятий твір, співвідношення інтелектуального і чуттєвого в процесі сприйняття творів. І хоча всі відповіді були індивідуальними, нам вдалося систематизувати найбільш переконливі думки і судження підлітків.

Другий напрямок першого етапу передбачав зацікавленість учнів музичним мистецтвом в процесі фортепіанного навчання. Він спрямовувався на теоретичне та практичне освоєння музичних знань з метою формування у підлітків музично-естетичної компетентності, наповнення музично-інтонаційного словника, розширення музичноестетичного світогляду і активізації емоційних вражень.

Учням пропонувалося оволодіти методами ескізного ознайомлення з музичними творами та читання 3 аркуша. Для роботи за цими методами було розроблено репертуарний список, до якого були включені нескладні для виконання, але різнобічні за змістом та жанром твори, наприклад, І. Шамо «Скерцо», В. Кирейко «Колискова», В. Барвінський «Думка». На індивідуальних заняттях педагог методом музичноестетичного навіювання направляв увагу учнів на особливості композиторського стилю, емоційно-образного змісту, засоби художньої виразності, і головне, - на виявлення музично-естетичної цінності даних творів.

Завдяки проведеній роботі на цьому етапі дослідження було визначено основні напрями формування музично-естетичної компетентності підлітків, значно підвищено рівень їх комунікативно-емоційної взаємодії та пізнавальної мотивації, закладено основи ціннісного ставлення до музично-естетичної діяльності та перспективного бачення процесу власного фортепіанного зростання. 
Другий етап (інтелектуально-поглиблюючий) спрямовувався на теоретичне та практичне освоєння музичних знань 3 метою формування у підлітків музичноестетичної компетентності, наповнення музично-інтонаційного словника, розширення музично-естетичного світогляду, активізації емоційних вражень, співставлення власних переживань 3 художньо-образним змістом твору, накопичення музичного тезаурусу та музично-виконавського досвіду. Цей етап грунтувався на гедоністичному, компетентнісном та жанрово-стильовому підходах з орієнтацію на принципи ідеального та еталонного в музичному мистецтві, міжкультурного діалогу, естетизації змісту навчання; при цьому реалізовувалися такі педагогічні умови: постійного оновлення музично-інтонаційного словника підлітків в процесі фортепіанних заняття, розвиток здатності до повноцінного сприйняття музичних творів та використання фортепіанної музики для дітей та юнацтва. Завдання даного етапу передбачали розвиток емоційної чутливості, оволодіння навичками комунікативної взаємодії, стимулювання прагнень на оволодіння художньою інформацією. Було використано методи музично-естетичного узагальнення та музично-естетичного порівняння; передбачено використання творчопізнавальних завдань.

Завдання даного етапу передбачали розвиток емоційної чутливості, оволодіння навичками комунікативної взаємодії, стимулювання прагнень на оволодіння художньою інформацією. Враховуючи, що формування музично-естетичної компетентності підлітків передбачає i художньо-виконавський розвиток, до експериментальної методики були включені цікаві та різнохарактерні твори, використовувалися методи музично-естетичного узагальнення та музично-естетичного порівняння також передбачалося використання творчо-пізнавальних завдань.

Наприклад, знайомство учнів $з$ двома цікавими фортепіанними циклами сучасних композиторів В. Сильвестрова «Кітч-музика для фортепіано» і Чжан Чжао «Китайська фортепіанна мрія» відбувалося на груповому занятті в класі одного викладача. Так, під час знайомства з першим циклом учні дізналися, що він складається 3 п’яти частин, в яких провідною творчою настановою для автора стала медитативність - спосіб світовідчуття, зафіксований в музичному тексті, який в даному контексті став механізмом смислового творення міського романсу. В процесі обговорення підліткам було наголошено, що В. Сильвестров $€$ одним із найбільш своєрідних сучасних 
українських композиторів, світогляд якого дослідники відзначають як переважно ліричний [2, с. 17-19].

Натомість композитор Чжан Чжао у циклі «Китайська фортепіанна мрія» взяв за мету представити світу художню цінність китайської фортепіанної музики. Сенс своєї праці він виразив словами: «У моєму розумінні китайська мрія - це мрія нації, водночас, - це мрія кожного китайця, і це наша музична мрія як музичних працівників» [4, с. 3234]. Під час знайомства $з$ циклом увага учнів зверталась на цікаву драматургію твору, а саме, цикл «Китайська фортепіанна мрія» складається 3 чотирьох частин, в яких «переплітаються час і простір». У кожній з них фортепіано імітує звучання дзвонів або курантів, тим самим символізуючи відлік часу. Бій курантів відзначає епохи китайської цивілізації від давнини до сучасності. Так, у першій частині відображене героїчне минуле китайського народу, а друга - це нагадування про велике потрясіння нації від західної промислової революції. Третій удар дзвону символізує тріумф революції, повстання народу проти несправедливості і відродження національної економіки. Четвертий удар - це майбутнє Китаю, його процвітання і культурне відродження, здійснення китайської мрії (зайняти провідне місце в сучасному світі).

Наступним було ескізне ознайомлення та самостійна робота над згаданими творами. На прослуховуванні у класі використовувався метод виконавської демонстрації, тобто учні експериментальної групи представляли свої інтерпретаційні задуми й анотації, а потім їх обговорювали та відстоювали власну виконавську позицію. Після завершення прослуховування учні перейшли до виконання нового проблемнопошукового завдання: відібрати та систематизувати за відповідним характером твори інших композиторів з власного репертуару та репертуару своїх товаришів. Результати виконання цього завдання засвідчили інтерес підлітків до пошуку нових творів. Вони відзначили, що такий пошук завжди є цікавим, оскільки допомагає їм ознайомитись із новими творами.

Третій (творчо-збагачувальний) етап спрямовувався на розвиток здатності до жанрово-стильового втілення інтерпретаційних задумів, творчого оцінювання музичних явищ на основі прийнятої у суспільстві системи цінностей; вироблення вмінь емоційновольової регуляції концертних виступів, розвиток інтелекту і музикальності. Цей етап грунтувався на акмеологічному, гедоністичному та компетентісному підходах із 
використанням принципів творчого універсалізму та міжкультурного діалогу, ідеального та еталонного в музичному мистецтві.

Під час його проведення реалізовувалися такі педагогічні умови: постійного оновлення музично-інтонаційного словника, розвиток музично-естетичного світогляду, оволодіння уміннями художньої інтерпретації музичних творів. Ми прагнули адаптувати підлітків до концертних виступів, що вимагало виховання емоційно-вольових якостей, вміння тримати себе на сцені, спрямовуючи увагу на виконання творчих завдань. Враховуючи набутий на попередніх етапах музично-естетичний досвід підлітків, активно використовувалися дискусійні та творчі, ілюстративні та сюжетні методи, проблемнопошукові форми навчання.

Важливим напрямком у оновленні музично-інтонаційного словника підлітків вважали вивчення поліфонічних творів. Зазначимо, що цей феномен як атрибут художнього діалогу представлений в музичному мистецтві, літературі, поезії, драматургії, архітектурі, живописі. В музичній педагогіці поліфонія застосовується в процесі навчання учнів різного шкільного віку, при цьому виконання поліфонічних творів є одним із найскладніших завдань фортепіанного навчання. Поряд із розвитком різних виконавських умінь (художньо-технічних, імпровізаційних, темпо-ритмічних, педалізації та тембрального забарвлення, музично-виконавської артикуляції) уміння виконувати поліфонічні твори стають важливою складовою музично-естетичної компетенції підлітків. Відтак із учнями експериментальної групи була проведена бесіда «Особливості поліфонічної музики», в процесі якої розглядались та демонструвались поліфонічні твори Й. Баха, Й. Брамса, П. Хіндеміта, М. Регера, Д. Шостаковича та відомого китайського композитора Хуан Цзи. У процесі бесіди було відзначено поліфонічний доробок українського композитора В. Бібіка, зокрема його цикл «24 прелюдії і фуги», про який Л. Грабовський писав: «Думаю, що такого фундаментального, значного, оригінального, багато в чому новаторського циклу прелюдій i фуг після П. Хіндеміта і Д. Шостаковича ще не було написано» [7].

Після ознайомлення із значною кількістю поліфонічних творів підлітки прийшли до висновку, що їх виконання потребує артистичної зрілості та широти світогляду. Глибина та краса музичної думки композитора вимагає від виконавця широких знань і всебічних навичок, тонкого музичного смаку і багатого інтелекту. Отримані дані 
наприкінці третього етапу засвідчили значне підвищення рівня всіх компонентів музично-естетичної компетентності. Зокрема, підвищилась мотивація до фортепіанного навчання, вони почали активніше набувати знання та уміння 3 метою яскравого та емоційного виконання музичних творів. Підлітки навчилися адаптуватися до власних концертних виступів, тримати себе на сцені, спрямовуючи увагу на виконання творчих завдань.

Висновки. Отже, результатом навчання підлітків у фортепіанних класах закладів позашкільної мистецької освіти стала позитивна динаміка сформованості музичноестетичної компетентності як цілісного та відносно стійкого особистісного утворення, що містить комплекс взаємопов'язаних мотиваційно-цільових, комунікативноемоційних, ціннісно-інтелектуальних детермінант, котрі забезпечують безперервний музично-естетичний розвиток та виконавське зростання підлітків.

\section{References}

1. Brudnov A.K. Sistema vospitaniya i dopolnitel'nogo obrazovaniya detey: ot idey do vnedreniya [System of upbringing and additional education of children: from ideas to implementation]. Pedagogika. 1999. No. 6. Pp. 26-32.

2. Zhalyeyko D.M. Try pohlyady ta try prochytannya: porivnyal'nyy analiz vykonavs'kykh versiy fortepiannoho tsyklu «Kitch-muzyka»V. Syl'vestrova [Three views and three readings: a comparative analysis of the performance versions of the piano cycle "Kitsch Music" by V. Silvestrov]. Visnyk KHDADM. 2014. No. 8. Pp. 16-21.

3. Mystets'ka osvita u vymirakh suchasnosti: problemy teoriyi ta praktyky. Naukova shkola Ol'hy Pylypivny Shcholokovoyi [Art education in the dimensions of modernity: problems of theory and practice. Scientific school of Olga Pylypivna Shcholokova] : [monohrafiya] / red.: O.M. Polatayko; Nats. ped. un-t im. M.P. Drahomanova. Dnipropetrovs'k : Adverta, 2014. $305 \mathrm{p}$.

4. Ni In. Sozdaniye «Kitayskoy mechty» dlya fortepiano. Na puti k utverzhdeniyu roli vostochnoy tsivilizatsii. Interv'yu s Chzhan Chzhao [Creation of "The Chinese Dream" for piano. Towards an assertion of the role of Eastern civilization. Interview with Zhang Zhao ]. Muzyka. 2015. No. 3. Pp. 32-34.

5. Pet'ko L.V. Linhvosotsiokul'turnyy pidkhid u vyvchenni amerykans'koyi novorichnoyi pisni «Jingle Bells» [Linguo-sociocultural approach in the study of American New Year's song "Jingle Bells"]. Topical issues of pedagogy: Collective monograph. Editoria di Modena, Roma, Italy. 2019. Pp. 31-58.

6. Pet'ko L.V. Stymulyuvannya tvorchykh zdibnostey pidlitkiv zasobamy vtilennya obrazu kazkovoho personazhu [Stimulation of creative abilities of teenagers by means of embodiment of an image of a fairy-tale character ]. Lyal'ka yak znak, obraz, funktsiya: Mater. 
vseukr. nauk.-prakt. konf. «Druhi Marka Hrushevs'koho chytannya» / za red. O.S. Naydena. Kyyiv. : VD «Stylos», 2010. Pp. 200-204.

7. Frayt O. Fortepianni al'bomy ta tsykly ukrayins'kykh kompozytoriv dlya ditey: istoriya $i$ suchasnist' [Piano albums and cycles of Ukrainian composers for children: history and modernity]. Drohobych : Vydavnytstvo DDPU im. I. Franka. 2010. 94 p.

8. Chen Kai, Shcholokova Olga. Methodological basis of the future musicians-educators performance-educational activity. Intellectual Archive. Toronto: Shiny Word.Corp. (Canada). 2018. (May/June). Vol. 7. No. 3. PP. 94-104.

9. Shcholokova Olga, Ding Yun. Pedagogical Principles of Young Pupils' Music Culture Formation in Piano Teaching Process. Intellectual Archive. 2015. Vol. 4. No. 6 (November). Toronto : Shiny Word Corp., 2015. Pp. 160-169.

\section{Translation of the Title, Abstract and References to the Author's Language}

\section{УДК 37.018.54:78].016:[37.015.31:7](043.3)}

Ляо Бінь. Організація експериментальної роботи 3 формування музичноестетичної компетентності підлітків у закладах позашкільної мистецької освіти.

У статті наголошується, що стан сучасної мистецької освіти України і Китаю вимагає впровадження в практику музичного навчання учнів позашкільних закладів освіти нових методик, спрямованих на формування їх музично-естетичної компетентності. Представлена поетапна методика охоплює фортепіанну підготовку учнів підліткового віку у двох площинах: виконавській і художньо-теоретичній, що передбачає наявність трьох етапів (організаційно-орієнтаційного, інтелектуальнопоглиблюючого і творчо-збагачувального).

Основним призначенням першого (організаційно-орієнтаційного) етапу навчання стало набуття у підлітків позитивної мотивації до музично-естетичної діяльності та розширенні тезаурусу музичних знань.

Другий (інтелектуально-поглиблюючий) етап був спрямований на теоретичне та практичне освоєння музичних знань з метою формування у підлітків музично-естетичної компетентності, наповнення музично-інтонаційного словника, розширення музичноестетичного світогляду, активізації емоційних вражень, співставлення власних переживань з художньо-образним змістом твору, накопичення музичного тезаурусу та музично-виконавського досвіду.

Третій (творчо-збагачувальний) етап спрямовувався на розвиток здатності до жанрово-стильового втілення інтерпретаційних задумів, творчого оцінювання музичних явищ на основі прийнятої у музичному мистецтві системи цінностей.

Ключові слова: музично-естетична-компетентність, позашкільні мистецькі заклади, фортепіанна підготовка, підлітки, методика фортепіанного навчання.

\section{Лimepamypa}

1. Бруднов А. К. Система воспитания и дополнительного образования детей: от идей до внедрения Педагогика. 1999. № 6. С. 26-32. 
2. Жалсйко Д. М. Три погляди та три прочитання: порівняльний аналіз виконавських версій фортепіанного циклу «Кітч-музика» В. Сильвестрова. Вісник ХДАДМ. 2014. № 8. С. 16-21.

3. Мистецька освіта у вимірах сучасності: проблеми теорії та практики. Наукова школа Ольги Пилипівни Щолокової : [монографія] / ред.: О. М. Полатайко; Нац. пед. унт ім. М.П. Драгоманова. Дніпропетровськ : Адверта, 2014. 305 с.

4. Ни Ин. Создание «Китайской мечты» для фортепиано. На пути к утверждению роли восточной цивилизации. Интервью с Чжан Чжао. Музыка. 2015. № 3. С. 32-34.

5. Петько Л. В. Лінгвосоціокультурний підхід у вивченні американської новорічної пісні «Jingle Bells» // Topical issues of pedagogy: Collective monograph. Editoria di Modena, Roma, Italy. 2019. Pp. 31-58.

6. Петько Л. В. Стимулювання творчих здібностей підлітків засобами втілення образу казкового персонажу. Лялька як знак, образ, функція: Матер. всеукр. наук.-практ. конф. «Другі Марка Грушевського читання» / за ред. О. С. Найдена. Київ. : ВД «Стилос», 2010. C. 200-204.

7. Фрайт О. Фортепіанні альбоми та цикли українських композиторів для дітей: історія і сучасність. Дрогобич : Видавництво ДДПУ ім. І. Франка. 2010. 94 с.

8. Chen Kai, Shcholokova Olga. Methodological basis of the future musicians-educators performance-educational activity. Intellectual Archive. - Toronto: Shiny Word.Corp. (Canada). 2018. (May/June). Vol. 7. No. 3. PP. 94-104.

9. Shcholokova Olga, Ding Yun. Pedagogical Principles of Young Pupils' Music Culture Formation in Piano Teaching Process. Intellectual Archive. 2015. Volume 4. No. 6 (November). Toronto : Shiny Word Corp., 2015. Pp. 160-169. 